\title{
Shareholders' Value Analysis: Eva \& Mva In Relation To Stock Market Returns With Reference To the Indian Cement Industry
}

\author{
*Mr. K.Kiran Kumar, **Dr. D.A.R. Subramanyam, \\ *Research Scholar, Acharya Nagarjuna University, Guntur, Andhra Pradesh, e-mail: \\ **Principal, Mahatmagandhi College, Guntur, A.P
}

\begin{abstract}
Understanding the value analysis and value creation of a company is essential for every financial manager in different situations. The value determination is carried out in various situations which may give positive or negatives results, resulting in serious jolts to the shareholders as well as to the goodwill of the company. Therefore, examining the shareholder value analysis is required to understand financial performance and it is critical to know whether modern techniques are supportive in creating value to the shareholders or not. This paper study the value analysis through modern techniques such as Economic Value Added (EVA), Market Value Added (MVA) and Stock Market Returns (StMr) of select twenty cement companies in India. This study evaluates the performance of the selected companies in terms of economic profit and market value and also tries to find the important metric among selected variables for creating shareholder wealth. In this study, twenty companies have been selected based on their market capital in Indian cement industry during the decade of 2005-06 to 2014-15. The study uses statistical tools for selecting the best metric among the variables through Mean, Coefficient and Multiple Regressions with Stepwise method with the help of SPSS.
\end{abstract}

Key Words: EVA, MVA, Stock Market Returns, Rank Correlation and Stepwise Multiple Regression Method

\section{Introduction}

In modern investment markets creating value to the shareholders and maximizing their wealth are the main objectives of companies. The Shareholder Value Creation means creating value to its shareholders by applying various metrics which comes under the 'Value Based Management' (VBM) techniques. Earlier, companies have been measuring their financial performances in terms of net profit or long-term returns. Thus the shareholder value analysis indicates that a company's success can be measured on the basis of the company's strategies and how it helps to enhance its value to the shareholders. Currently, companies have been applying the method of Shareholder Value Analysis (SVA) and it has become a popular method for measuring the shareholder value. The concept of VBM shows how the interest of the shareholders will be affected by the management decisions which are related to investment and other areas. The SVA is created only when the long term profits exceeds over the cost of capital. However, the same in reverse would result in decreased SVA. The simple rule of SVA is that a company adds value for its shareholders only when its equity returns exceeds the cost of capital. So whenever a company needs to calculate its value it is necessary to take steps to improve its performance. Shareholder Value Analysis is a comprehensive concept of corporate finance to understand the financial performance of the companies. In general, most of the scholars accept the meaning of SVA as to how management/directors' decisions affect the net present value or the firm value of the company. At the corporate level, SVA stipulate a structure for estimating the selections for raising the shareholder value by determining the trade-offs between either re-investing in the current business or investing in new businesses and distribute the profits to its stockholders in the form of dividends. The investment decisions are usually taken by the companies' management. However, they should take into consideration, the interest of its shareholders because they are the real owners of the company and the value created should maximize their returns. The SVA is not a novel method to measure value creation. It was developed in the 1980's by Rappaport and other consultant firms. The practical adjustments for debt, risk and costs of capital are important factors for calculating the shareholder value creation. The metrics such as Economic Value Added (EVA) and Market Value Added (MVA) use these factors in their adjustments. The EVA determine the economic profit of the company over a period of time and the economic profit will be calculated based on the Net Operating Profit after Tax (NOPAT) and overall cost of the company. When NOPAT exceeds the cost of capital it means that it is generating economic profit, whereas, when NOPAT is less than the cost of capital it decreases the shareholders' value. The MVA also explains about value creation, where market value is considered to be created when it is higher than the book value and when it is less than book value it reduces the market value. This study tries to find the superior proficiency between EVA and MVA in relation to stock market returns with selected cement companies during the financial period of 2006 to 2015 which are traded actively in the Bombay Stock Exchange (BSE). Further, the paper studies the EVA and MVA for finding out which one is highly significant in relation to Stock Market Returns. 


\section{Literature Review}

Angayarkanni\&Anand Shankar Raja.M(2014) studied capital structure and measuring its impact of EVA; a case study of the Bimetal Bearing Limited. The analysis concludes that Bimetal bearings Ltd., have used the debt-equity capital to the satisfactory level during the study period. The company has used more equity capital than the debt capital, instead of firm can increase the debt content which may reduce the weighted average cost of capital(WACC) and increase the value of the firm. Asha Sharma(2013)-her study describes that the value creation strategy of Infosys by analyzing whether EVA represents better the market value of company in relation to regular performance measures. The EVA recognized important tool of performance measurement and management all over the world, particularly in advance economies by adopting it as corporate strategy. Rajesh\&Ramana Reddy et al. (2012) examined a comparative study between EVA and MVA for the selected cement companies in India and found that EVA and MVA play significant role in order to evaluate the financial performance of the companies. The findings proved the two measures (EVA and MVA) provide reliable shareholder's value creation activities. Sharma\&Kumar(2010) Both are presented a narrative literature reviews of published papers on Economic Value Added from 1994 to 2008. They found that reviews that have been done in advanced economy have essentially found to be supporting EVA as compared to less developing economies. Aminimehr \&Iqbal(2008), studied through the trend analysis and Pearson correlation analysis in relationship between EVA and MVA. The analysis found that there is significant negative relationship between EVA and MVA. Mahmood, et al.(2008) study the role of EVA to identify Malaysian property companies from the year 1997 to 2006 and found that many of the corporate companies failed to cover the shareholder's wealth.

Vishwanandham \&Luthara (2005) This study used strategic profit model (SPM) and the economic valueadded (EVA to measure shareholder value). SPM measures the Return on Net worth (RONW) which is defined as the Return on Assets (ROA) multiplied by the financial leverage. Both, RONW and EVA give an indication of how much shareholder value a firm creates to its shareholders. With the increasing focus on shareholder value creation and main competencies, most of the firms are outsourcing their information technology (IT) related activities to third party software businesses. Indian software companies become leaders in providing these services. Companies from several other countries are also competing for the top slot. Lange(2000), examined the concept that, Shareholder value has increasing acceptance as a measure of a company's performance in global capital markets. Risk management has also elevated its profile in the wake of significant corporate disasters. Value Based Management(VBM) supports the organization's objectives of shareholders and the financial markets. Risk Management is an important role in this procedure through the identification of threats (i.e., internal and external to an organization's objectives).

\section{STATEMENT OF THE PROBLEM}

\section{Research Methodology}

Economic Value Added and Market Value Added have become the most popular tools for managers to measure financial performance of companies. These metrics act as guidelines for strategic and profitable investment decisions. EVA and MVA have attained increased importance in influencing the investment, dividend and financing decisions and also overall cost of capital. Thus EVA and MVA have a crucial role in value creation and the financial performance of the companies. The existing research and literature only examines the relationship between EVA and MVA. This article will focus on the impact of the EVA and MVA in relation to stock market returns. It will also identify the superior measure among these two through which the stepwise multiple regression model for creating value to the share-holders. Moreover, the paper will also study the rank correlation based on EVA and MVA of 20 select cement companies in India based on their capital.

\section{OBJECTIVES OF THE STUDY}

1. To study the financial performance of the Cement Industry in India through EVA and MVA;

2. To rank the selected cement companies based on EVA and MVA Performances;

3. To identify the measure-proficiency of EVA and MVA in relation to Stock Market Returns.

\section{TOOLS OF ANALYSIS:}

Financial Tools: Economic Value Added, Market Value Added and Stock Market Returns

(a) Economic value added (EVA): is one of the shareholder value technique for evaluating firm's financial performance based on the residual income. EVA is calculated by deducting the company's overall cost of capital from its Net Operating Profit after Tax (NOPAT) deductions. When calculated, the EVA shows positive value which means that it creates value for their shareholders whereas the negative EVA indicates the decrease in the shareholder value as well as firm value. In simple words, NOPAT should exceed the overall cost of capital of the firm to give a positive EVA. This technique explains the organizational performance according to the companies' goals which are formulated by the management. The primary 
goal of every company is to maximize the shareholder wealth and minimize the cost. Therefore, EVA is required to evaluate the financial performance of the companies.

EVA is calculated as:

$$
\text { EVA }=\operatorname{PBT}(1-\mathrm{t})-(\text { Capital Employed } * \text { cost of capital })
$$

Whereas,

PBT $=$ Profit before Tax multiplied with (1-t)

Capital employed $=$ combination of Net worth and Debt multiplied with cost of capital

(b) Market value added (MVA): It us another foremost technique of shareholder value analysis and it is denoting as wealth creation technique which is created by company for its shareholders. It is calculated based on the market share price and market value should be more than book value of the company. Here, market value is calculated with the current market share price and compare with the book value of the firm which is recorded in the balance sheet, when market value exceeds the book value means that it creates value to the firm and vice-a-versa. It is required to calculate whenever the company share prices are too oscillated in the stock exchanges, and also warn the financial managers and investors to see the problems whether it is affecting only particular industry or market.

MVA = Market Value (total no of shares * market share price) - Book value of Equity

Statistical Tools: Rank Correlation and Stepwise Multiple Regression Regression Model

To know the superiority of a particular measure, the study applied Step-wise regression between StMR and EVA \& MVA, with the assumption there is a linear relationship between StMR and EVA \& MVA. The following are the simple regression equations.

$$
\begin{aligned}
& \text { StMRij }=a_{i j}+b_{i j} E E_{i j}+e_{i j} \\
& \text { StMRij }=a_{i j}+b_{i j} M_{i j}
\end{aligned}
$$

\section{FORMULATING HYPOTHESIS}

$>$ Null Hypothesis $\mathbf{H}_{0}$ : Both EVA and MVA are not significant to measure the financial performance of the select cement companies of the study.

$>$ Alternate Hypothesis $\mathbf{H}_{1}$ : Both EVA and MVA are significant to measure the financial performance of the select cement companies of the study.

\section{Data Analysis And Interpretation}

In order to confirm that the measure-proficiency of EVA is better than MVA, the study reviews, analyze and identifies the relationship between EVA, MVA and Stock Market Returns and its impact on the shareholder value and firm value. Moreover, ranks are given based on the EVA and MVA performances for 20 select cement companies in India through rank correlation method to identify the best company among these. The following calculations prove the above assumption:

Table No: 1 R Statistics

\begin{tabular}{|c|c|c|c|c|c|}
\hline Model & Sum of Squares & df & Mean Square & $\mathrm{F}$ & Sig. \\
\hline Regression & 3600.646 & 1 & 3600.646 & 3.663 & .092 \\
\hline Residual & 7864.876 & 8 & 983.110 & & \\
\hline Total & 11465.522 & 9 & & & \\
\hline
\end{tabular}

\begin{tabular}{|l|l|l|l|l|}
\hline \multicolumn{1}{|c|}{ Model } & \multicolumn{1}{|c|}{ R } & \multicolumn{1}{c|}{ R Square } & Adjusted R Square & Std. Error of the Estimate \\
\hline 1 & $.560^{\mathrm{b}}$ & .314 & .228 & 31.35458 \\
\hline
\end{tabular}

Table: 2 Analysis of Variance

a. Dependent Variable: StMr, b. Predictors: (Constant), EVA 
Table No: 3 Coefficients

\begin{tabular}{|c|c|c|c|c|c|}
\hline \multirow[t]{2}{*}{ Model } & \multicolumn{2}{|c|}{ Unstandardized Coefficients } & Standardized & \multirow[t]{2}{*}{$\mathrm{t}$} & \multirow[t]{2}{*}{ Sig. } \\
\hline & B & Std. Error & Beta & & \\
\hline (Constant) & 32.834 & 10.040 & & 3.270 & .011 \\
\hline EVA & .003 & .002 & .560 & 1.914 & .092 \\
\hline
\end{tabular}

a. Dependent Variable: StMr

In the above analysis, stock market returns is considered as dependent variable and EVA \& MVA are considered as independent variables. The analysis applied step-wise multiple regressions through backward method to statistically eliminate the insignificant independent variables from the selected metrics. This method eliminated MVA from the model as a result making EVA statistically significant in relation to stock market returns. The analysis also conveys that EVA is the superior measure in comparison to MVA in identifying the shareholder and firm value creation.

The EVA $22.8 \%$ variance is accounted for creating value to the shareholders in relation to stock market retruns. The output table no:2 on F-Test shows that the 3.663 significance with $1,8,9$ degrees of freedom, at $0.05 \%$ level and null hypothesis is rejected. The estimated multiple regression analysis after applying 'step-wise regression through backward method' is as follows:

$$
\begin{aligned}
& \mathrm{StMR}=\alpha i \mathrm{ij}+\beta \mathrm{ij} \text { EVAij }+ \text { eij } \\
& \mathrm{StMR}=32.83+0.03 \mathrm{EVA}
\end{aligned}
$$

Table no5 shows various companies ranks on the basis of average of EVA and some of the companies are having positive EVA and remaining companies i.e., Anjani Cement, Birla Cement, Deccan Cement, Heidelberg Cement, India Cement, Jai Prakash Association, JK Cement, Lanco, Panyam cement and Shiva cement showing negative. The study revealed that the first rank position is occupied by Ultra Tech Cement Ltd., with $1037.68 \mathrm{cr}$; Ambuja Cement in second position with 719.74 and the KCP Cement came third with by $266.27 \mathrm{cr}$. It clearly says that positive companies are generating value or wealth to their shareholders during the said period of time. Therefore, investors can invest in these companies for generating returns as well as creating value to the company. Moreover, those companies which are having negative EVA shows that they are not giving priority to create wealth and indirectly destroys the value/wealth of the firm during the study period.

The market value added ranking reveals the following details of the select cement companies during the period of study. In this analysis all most all cement companies registered positives, and it means that all cement companies are creating market value to the shareholders. The ranking based on the average market values gives first position to Ultra Tech Cement Ltd., with 361612.7cr market value and the second is Mangalam Cement Company with 37555.82cr market value and third to Birla Cement Corporation with $22496.94 \mathrm{cr}$ market value. The rank correlation between EVA and MVA is $0.44 \%$ of selected cement companies during the study which means that both EVA and MVA have adequate relation for creating value added to its shareholders.

\section{Conclusion}

The study reveals that the shareholder value analysis done through economic value added and market value added in relation to stock market returns can help in identifying the superior measure. It can be stated that both EVA and MVA played significant roles in the financial performance of the select cement companies. The study ranked the correlation between the companies based on the EVA and MVA and the statistics brought the Ultra Tech Cement Company into first position by both metrics. The study applied step-wise multiple regressions through backward method to statistically eliminate the insignificant independent variable from the selected metrics. This method eliminated MVA from the model, making the EVA into the statistically significant in relation to stock market returns; in turn helping to reach the conclusion that the EVA is the best superior measure for creating value to its shareholders in relation to stock market returns.

\section{References}

[1] Arora, Asha, Anand, Manoj, Garg and Ajay- "Economic Value Added: Business performance measure of shareholders' value", The Management Accountant, May 1999.

[2] Banerjee.A - "Economic Value Added and Shareholder Wealth: An empirical study of relationship", Paradigm, Vol. 3(1),pp-133, (1997, 1999)

[3] Feltham,C(2000). Investment Basics EVA- The Real Key to Creating Value, Investment Analysis Journal, summer-1995, No:40.

[4] Hall,J.H and L,M. Brummer, "The Relationship Between the Market Value of a Company and Internal Performance Measurements" Working Paper, University of Pretoria, [Online].<http:// ssrn.com/ abstract_id=141189>, (2001)

[5] Mekkonen(2002)“Measuring and Ranking Value Drivers”- Tinbergan Institute Discussion Paper, http://papers.ssrn.com/sol3/papers.cfm?abstract_id=310 999

[6] Kim.G.W-EVA and Traditional Accounting Measures-which Metric is a better predictor of market value of hospitality companies? Journal of Hospitality and Tourism Research, 30(1)- pp- 34-49 (2006). 
[7] N.R.V. Ramana Reddy, M.Rajesh and Dr.T.Narayana Reddy(1999) "Valuation through EVA and Traditional Measures an Empirical Study"- IJTEF-Vol.2- No.1.

[8] Sakthivel.N.,(2011)- "Shareholders' Value in Indian Pharmaceutical Industry- An Empirical Analysis", Indian Journal of Commerce \& Management Studies, Vol. II, No. 1 January, pp 87-99.

[9] Kaur. M, and Narang. S(2009)- Shareholder Value Creation in India e Most Valuable Companies- An Empirical Study. The Icfai Journal of Management Research,8(8), 16-42.

[10] Pratapsinh Chauhan(2012)- "Shareholders Value Creation in Indian Petroleum Industry- An Empirical Analysis"- International Conference on Business, Economics, Management and Behavioral Sciences (ICBEMBS'2012) Jan. 7-8, Dubai.

\section{Appendix -I}

Table No:4 Financial Performance of selected Cement Companies in India. Aergae values of EVA and MVA

\begin{tabular}{|l|l|l|l|}
\hline \multicolumn{1}{|c|}{ Years } & \multicolumn{1}{c|}{ StMr } & \multicolumn{1}{c|}{ EVA } & \multicolumn{1}{c|}{ MVA } \\
\hline 2015 & 81.08 & 5220.25 & 571939.6 \\
\hline 2014 & -13.98 & -17350.3 & 242101.1 \\
\hline 2013 & 32.25 & 4804.23 & 236624 \\
\hline 2012 & 23.63 & 6937.21 & 176168.9 \\
\hline 2011 & 20.79 & 1693.96 & 201746.1 \\
\hline 2010 & 75.91 & 3436.97 & 250844.7 \\
\hline 2009 & -13.84 & -905.75 & 82216.79 \\
\hline 2008 & 43.43 & 2433.08 & -16492.1 \\
\hline 2007 & 25.39 & 2391.86 & 173794.8 \\
\hline 2006 & 83.88 & 1638.12 & 229863.1 \\
\hline Mean & $\mathbf{3 5 . 8 5 4}$ & $\mathbf{1 0 2 9 . 9 6 3}$ & $\mathbf{2 3 3 0 2 2 . 5}$ \\
\hline S.D & $\mathbf{3 5 . 6 9 2 3 9}$ & $\mathbf{6 8 2 0 . 7 8 6}$ & $\mathbf{1 2 9 2 6 5 . 4}$ \\
\hline
\end{tabular}

Table No: 5 Rank Correlations between EVA and MVA of selected cement companies in India

\begin{tabular}{|c|l|r|r|c|c|}
\hline S.No & Name of the Company & EVA & MVA & EVA Rank & MVA Rank \\
\hline 1 & ACC Cement & 54.28543 & 13186.27 & 9 & 4 \\
\hline 2 & Ambuja Cement & 719.7448 & 10357.77 & 2 & 6 \\
\hline 3 & Anjani Cement & -162.646 & 5661.317 & 21 & 10 \\
\hline 4 & Barack Cement & 83.2252 & 3012.585 & 7 & 13 \\
\hline 5 & Birla Cement Corp & -37.9359 & 22496.94 & 15 & 3 \\
\hline 6 & Deccan Cement & -6.73802 & 2050.893 & 12 & 16 \\
\hline 7 & Heidle Cement & -20.5478 & 7792.305 & 14 & 8 \\
\hline 8 & India Cement & -4.60146 & 602.5528 & 11 & 21 \\
\hline 9 & Jai Prakash & -38.7446 & 1854.181 & 16 & 18 \\
\hline 10 & JK Cement & 79.31787 & 2038.528 & 8 & 17 \\
\hline 11 & JK Lakshmi & -141.74 & 8915.019 & 20 & 7 \\
\hline 12 & KCP Cement & 266.2771 & 2088.945 & 3 & 15 \\
\hline 13 & Lanco Cement & -71.083 & 5823.746 & 17 & 9 \\
\hline 14 & Mangalam Cement & 24.03756 & 37555.82 & 10 & 2 \\
\hline 15 & NCL Cement & 195.824 & 12812.92 & 4 & 5 \\
\hline 16 & Panyam Cement & -14.5376 & 1141.674 & 13 & 20 \\
\hline 17 & Ramco Cement & -94.246 & 3615.572 & 18 & 11 \\
\hline 18 & Sagar Cement & 91.635 & 3494.535 & 6 & 12 \\
\hline 19 & Shiva Cement & -106.096 & 1591.97 & 19 & 19 \\
\hline 20 & Shree Cement & 180.2786 & 2456.503 & 5 & 14 \\
\hline 21 & Ultra Tech Cement & $\mathbf{9 6 . 8 2 8}$ & $\mathbf{2 8 6 . 3 7}$ & $\mathbf{1 7 9 2 7 0 . 3}$ & Rank Corr = \\
\hline
\end{tabular}

